\title{
Metafisika Politik: Menimbang Kekuatan Aristokrasi dalam Pilkada Belu dan Malaka Tahun 2020
}

\author{
Political Metaphysics: \\ Considering the Aristoctic Power in the 2020 General Election of District Heads \\ in Belu and Malaka Regencies
}

\author{
Hendrik Saku Bouk \\ Ilmu Komunikasi-Universitas Katolik Widya Mandira, Kupang \\ E-mail: boukobor@yahoo.co.id
}

\begin{abstract}
This writing intends to describe the carrying out of election of district heads of Belu and Malaka regencies of the East Nusa Tenggara Province in December 2020. This paper is of the opinion that the election of district heads in these two regencies involved the perspective of political metaphysics. According to indigenous tradition of the Belunese and the Malakans, the metaphysical power is transformed into the personality of the raja. Raja is the representation of the divine, the incarnation of god (Maromak Oan) and endowed politically with rights to govern. In the general election of the Malaka and Belu district heads, the pair candidates running for the posts of regent and vice regent did their best to win the electoral contestation by building their political power through the coalition of political parties, through campaign for mass support, through political physics that mobilizes all political machinery as well as through pataphysics that make use of the virtual networks. Nevertheless, the coalition of political parties still take into account the power of metaphysical politics based on aristocracy. The nobilities are considered worthy to become the persons endowed with privileges to govern. Therefore the election of district heads does not necessarily always have to do with coalition, campaign and money politics, but also with tradition and belief of the voters who demonstrate their preference to the candidates from the aristocratic circles.
\end{abstract}

Keywords: general election of district heads (pilkada), democracy, metaphysics, aristocracy politics

\begin{abstract}
Abstraksi
Tulisan ini bertujuan untuk menjelaskan perhelatan pemilihan kepala daerah Kabupaten Belu dan Malaka di Nusa Tenggara Timur pada Desember 2020. Paper ini berpandangan bahwa pilkada di dua wilayah ini melibatkan perspektif metafisika politik. Menurut tradisi budaya orang Belu-Malaka, kekuatan metafisika ini menjelma dalam diri seorang raja. Raja adalah representasi yang Ilahi, titisan dewa (Maromak Oan) yang secara politis mendapat hak istimewa untuk memerintah. Dalam pilkada Belu dan Malaka, para pasangan calon bupati dan calon wakti bupati berusaha untuk mencapai kemenangan dengan cara membangun kekuatan politik melalui koalisi partai-partai, dukungan massa dalam kampanye, kekuatan fisika politik dengan menggerakkan seluruh kekuatan mesin politik, kekuatan patafisika melalui jaringan virtual. Walaupun demikian, partai-partai koalisi mesti tetap mempertimbangkan kekuatan metafisika politik berbasis aristokrasi. Bangsawan adalah sosok yang pantas mendapat hak istimewa untuk memerintah. Karena itu, pemilihan kepala daerah tidak semata-mata karena pengaruh koalisi, kampanye dan politik uang - melainkan juga karena pengaruh tradisi budaya dan keyakinan sebagian besar massa pemilih yang masih kuat bersimpati pada paslon yang berasal dari kalangan 'istana'.
\end{abstract}

Kata Kunci: Pilkada, demokrasi, metafisika, politik-aristokrasi 


\section{Pendahuluan}

Pemilukada adalah pesta demokrasi bagi seluruh rakyat. Pemilihan Kepala Daerah serentak di Indonesia untuk 270 wilayah, termasuk sembilan (9) kabupaten di wilayah Nusa Tenggara Timur tetap digelar walaupun pandemi Covid-19 masih terus menguat. Pendaftaran calon dibuka bulan Agustus 2020, sedangkan penetapan nama calon secara resmi pada tanggal 6 September 2020 sehingga tersedia waktu tiga bulan bagi para kandidat melakukan kampanye. Kampanye bisa dilakukan melalui tatap muka dengan tetap memperhatikan persyaratan protokol kesehatan Covid- 19 dan kampanye online melalui media massa dan media jejaring sosial. Aloysius Budi Purnomo (2009) melukiskan kampanye juga bagian dari pemasaran politik. Kampanye itu sama dengan iklan, menawarkan produk. Produknya ialah kandidat jagoannya dengan visi, misi dan program kerakyatannya. Karena itu masyarakat mesti serius membaca situasi politik yang selalu berubah-ubah setiap saat. Dalam kampanye sering ada produk yang tidak laku dijual di tengah masyarakat pemilih, walaupun kandidatnya berkualitas, disebabkan antara lain juga karena kesalahan para penjualnya yakni Tim sukses cenderung menjelekkan produk (kandidat) lain.

\section{Isu "Politik Kerabat"}

Indonesia menganut sistem demokrasi didasarkan pada pilihan bebas rakyat. Kampanye bertujuan menarik hati rakyat dan usaha menjadikan sang kandidat terpilih dan menang. Walaupun demikian, menurut dugaan banyak pihak, pilkada tahun 2020 ini, yang terpenting bukan soal kampanye untuk menjual visi, misi, program dan kualitas kandidat guna mendulang suara rakyat pemilih, bukan pula soal saling mendiskreditkan di antara para kandidat dalam mempengaruhi massa pemilih guna meraih bola panas kekuasaan - melainkan pada kedekatan relasi kekerabatan antara kandidat dengan pejabat negara. Maka ada yang menyebutnya dengan istilah 'politik kerabat'. Itulah sebabnya, pilkada 2020 dinilai unik karena dibayang-bayangi oleh isu kekuasaan atas dasar relasi kekerabatan atau lebih tegas disebut oligarki kekuasaan, pada hal Indonesia menganut sistem demokrasi yang bertujuan memeratakan kekuasaan dan ekonomi. Oligarki merupakan suatu sistem pemerintahan dengan kekuasaan politik dipegang oleh sekelompok kecil elit yang berasal dari masyarakat, yang dapat dibedakan berdasarkan keluarga, kekayaan serta kekuatan militernya. Kata oligarki sendiri berasal dari bahasa Yunani yaitu "oligarchia", dari kata oligoi yang berarti sedikit dan arkhein yang memiliki arti memerintah. Awal mula sistem pemerintahan oligarki pertama kali terjadi pada negara Yunani Kuno (https://ilmugeografi.com/ilmusosial/pemerintahan-oligarki).

\section{Tiga Relasi Kekuatan Politik}

Terlepas dari isu politik relasi kekerabatan atau politik oligarki yang menguat pada pilkada serentak tanggal 9 Desember 2020, Yasraf Amir Piliang (2009) dalam opini berjudul, "Patafisika Politik" menjelaskan bahwa untuk meraih kekuasaan dalam suatu pemilihan biasanya arsitektur (tubuh) politik bangsa maupun daerah dibangun oleh tiga relasi kekuatan politik ini:

1. "Fisika Politik". Sesungguhnya politik merupakan upaya sistematis-pragmatis yang bermuara pada kekuasaan dengan cara mengerahkan dan menggerakkan segala 
'kekuatan' fisik konkrit berupa finansial, material, ekonomi, keluarga, budaya, militer, individu, kelompok, massa, teknologi, infrastruktur, termasuk bantuan sumbangan dan hadiah seperti jaket, kaus, topi, masker bertuliskan nama kandidat. Yasraf Amir Piliang (2009) mengatakan relasi kekuatan politik seperti ini, John Protevi dalam Political Physics (2002) menyebutnya 'fisika politik' (political physics) yaitu kekuatan politik fisik yang dibangun oleh totalitas kekuatan dalam aneka skala yakni individu, keluarga, kelompok, partai, korporasi, geng, sekte dan bangsa ; serta aneka jenis kekuatan lain seperti militer, modal, massa, premanisme, teknologi, partai politik dan kekuatan berbasis keagamaan. Selain itu, Yasraf Amir Piliang juga mengutib pendapat Felix Guattari dalam Molecular Revolution (1984) yang menyebut totalitas kekuatan politik fisik-konkrit ini sebagai "mesin konkrit" (concret machine) yakni mesin massa, mesin ekonomi, mesin industry, mesin uang. Semuanya dikerahkan sebagai modus politik untuk meraih bola panas kekuasaan. Kita dapat menyaksikan gerakan mesin konkrit politik ini bergulir di sejumlah wilayah di Nusa Tenggara Timur termasuk di Belu dan Malaka. Sejak saat pendaftaran calon, penetapan resmi calon hingga masa kampanye terlihat adanya pengerahan massa dalam jumlah tertentu disertai pembagian atribut politik (jaket, kaus, topi, masker yang bergambar foto dan bertuliskan nama calon). Bahkan menjelang proses pencalonan sudah terlihat dinamika 'mesin konkrit' itu dalam bentuk bantuan sosial (hadiah mobil, pengobatan gratis, bantuan sembako, pembangunan rumah ibadat, sekolah, jalan desa, traktor, rumah sehat, bibit tanaman, hewan dan sebagainya). Sejumlah pihak juga sudah memprediksikan adanya dugaan politik uang menuju hari ' $H$ '. Semuanya ini dilihat sebagai unsur-unsur 'mesin konkrit politik' dalam membangun kekuasaan.

2. "Metafisika Politik". Arsitektur politik bangsa maupun daerah juga dibangun oleh kekuatan "metafisika politik" (political metaphysics) yaitu upaya membangun kekuatan dengan suatu kekuatan lain yang melampaui fisik. Piliang (2009) menyebut dua kekuatan metafisik : pertama, yang berkaitan dengan yang transenden (Allah). Di Timor, misalnya, selama masa kampanye acapkali para kandidat mendapatkan kesempatan mendatangi para tokoh agama untuk mencari dukungan politik. Para calon sering mengawali dan mengakhiri kampanye politiknya atas nama Tuhan, rajin berdoa dan melakukan novena, menghadiri ibadat dan misa, serta terlibat aktif dalam doa Rosario di Kelompok Umat Basis (KUB) yang mudah dijadikan sebagai wadah untuk kampanye politik. Derma di gereja selama masa kampanye sering meningkat. Barangkali tidak terlalu keliru kalau kegiatan-kegiatan seperti ini boleh saya sebut kegiatan 'rohani politik' artinya kegiatan rohani yang dilakukan oleh para kandidat untuk tujuan kepentingan politiknya selama masa kampanye dan akan sirna sesudah pemilukada; kedua berkaitan dengan yang gaib (mistik). Para calon sering mencari dukungan politik pada kekuatan mistik, kekuatan gaib, paranormal (peramal), dukun, rumah pemali, roh leluhur, mengunjungi kuburan nenek moyang atau tokoh politik tertentu yang diyakini sebagai sosok 'ajaib' untuk mendapatkan kekuatan, termasuk pula menyembah batu keramat, pohon sakti, gunung dan laut serta ritual adat di rumah pemali yang diyakini dapat membantu menganugerahkan kekuasaan. Terkait kekuatan metafisik politik ini, acapkali paranormal atau dukun menggunakan kesempatan untuk menafsir 'nomor urut' pasangan calon bupati-wakil bupati sebagai 
'angka keberuntungan' atau 'angka ajaib', angka 'berkat', angka 'pilihan Tuhan'. Ada pula yang menggunakan hewan piaraan seperti kuda dan ayam jago merah (Tetun=manu meo) sebagai semiotik politik yang menyimbolkan keperkasaan, kekuatan, kepahlawanan, keberanian dan kemenangan

3. "Patafisika Politik". Tubuh politik juga dibangun oleh kekuatan patafisika politik yakni upaya menciptakan watak politik dengan membangun "kekuatan citra" melalui dunia virtual. Patafisika politik menjadikan seduksi imagologis sebagai pilar kekuasaan. Fisika politik mengerahkan kekuatan riil individu, keluarga, kelompok dan citra hanyalah 'medium' untuk penyampaikan pesan. Sedangkan dalam patafisika politik justru citra menjadi pesan itu sendiri. Citra adalah pesan. Citra politik menjadi bagian dari 'tubuh politik' karena tanpa citra terasa tidak ada kekuatan politik. Yasraf Amir Piliang (2009) merujuk pada pemikiran Jean Baudrillard dalam In the Shadow of the Silent Majorities (1981) yang menyatakan bahwa dunia politik sedang didominasi oleh kekuatan citra sebagai dunia "patafisika" (pataphysics) yang berkembang begitu pesat di era virtual ini. Dengan melemahnya kekuatan politik fisik dan metafisik dalam perkembangan politik di era virtual ini, menjadikan 'mesin citra' sebagai mesin penggerak utama dalam mengerahkan massa virtual. Citra-citra itu sangat menghipnotis perhatian dan kesadaran melalui aneka media : surat kabar, radio, televisi, handphone, internet, facebook dan media sosial lainnya. Bahkan citra-citra itu muncul sarat dengan manipulasi, seduksi, ilusi dan framing yang seolah-olah riil pada hal itu 'topeng' untuk menutupi 'ketiadaan realitas'. Karena itu menurut Piliang (2009), "patafisika politik" dinilai membawa 'absurditas politik' karena menyelewengkan realitas melalui 'citra realitas' sebagai suatu modus operandi politik yang dianggap legitimated. Dominasi 'citra realitas' atas realitas menggiring pada 'derealisasi politik' (derelaisation of politic) yaitu kekuatan politik dibangun oleh 'kekuatan citra manipulatif' pada tingkat semiotik dan bukan dibangun oleh relasirelasi konkrit, riil dan substansial pada tingkat realitas sosial harian. Di sini, 'semiotik politik' mengambil alih sosiologi politik'. Piliang melanjutkan bahwa dalam selebrasi politik citra, 'kekuatan citra' mengooptasi 'kekuatan rakyat' (demos) karena rakyat di abad virtual ini sudah hidup dalam pengaruh bayang-bayang 'seduksi citra'. Bahkan 'kekuatan citra' itu (diasumsikan) kini justru membentuk demos, sehingga kekuatan dan opsi untuk memilih pasangan calon tidak lagi lahir dari keputusan demos sendiri, melainkan seolaholah keputusan memilih itu dibuat berdasarkan 'keputusan kekuatan citra'. Pada tahap ini 'demokrasi' artinya kekuasaan ada di tangan rakyat mendapatkan makna baru sebagai 'imagokrasi' (imagocracy) yaitu kekuasaan ada di tangan gemerlap citra dan pencitraan. 'Seduksi politik' menggantikan program politik'. Yasraf Amir Piliang (2009) menilai arsitektur politik daerah yang dikembangkan dan dibangun di atas kekuatan: fisika politik, metafisika politik dan patafisika semuanya bermuara pada satu titik kulminasi ini: kekuasaan. Walaupun demikian, ketiga kekuatan itu dinilai bukan merupakan lukisan riil politik karena ketiganya bukan dibangun oleh kekuatan realitas, melainkan oleh kekuatan 'ilusi-ilusi' baik yang berkarakter fisik, metafisik maupun patafisik. Dengan demikiran arsitektur (tubuh) politik pilkada tidak murni dibangun oleh kekuataan realitas, melainkan oleh kekuatan 'ilusi'. 


\section{Menimbang Kekuatan "Metafisika Politik" Dalam Pilkada Belu dan Malaka 2020}

Terkait pilkada di Belu dan Malaka, setiap kandidat membangun strategi politiknya dalam perjuangan mempengaruhi rakyat pemilih selama masa kampanye untuk meraih kemenangan, antara lain melalui tiga jalur kekuatan ini:

\section{Koalisi Partai Politik}

Di Kabupaten Belu, Paslon Willy LayOse Luan (SAHABAT) mendapat dukungan dari koalisi enam (6) partai politik dengan jumlah kursi 16 : Demokrat (4 kursi), PDIP (4), Gerindra (3) PAN (3), Hanura (1) dan PPP (1). Sementara itu, Pasangan calon Agus Taolin-Aloysius Haleserens (SEHATI) didukung lima partai dengan jumlah kursi 14: Partai NasDem 4 kursi, Golkar 4 kursi, PKB 3 kursi, PKS 1 kursi dan PKPI 2 kursi (Teni Jehanas, Pos Kupang 3/9/2020). Sementara di Kabupaten Malaka paslon SBS-WT mendapat dukungan koalisi dari enam (6) partai politik : Golkar, Nasdem, Demokrat, Hanura, Gerindra, PDIP. Sementara paslon SN-KI didukung oleh tiga partai: PKB, PSI, Perindo. Walaupun demikian paslon ini berkeyakinan menang pada pilkada Malaka 2020 karena dukungan masyarakat akar rumput yang masih kuat sistem kekerabatannya.

Sekalipun partai-partai koalisi sudah menyatakan dukungan secara terbuka terhadap paslon tertentu, namun itu belum mutlak. Partai koalisi harus tetap memperhitungkan pilihan bebas masyarakat akar rumput karena koalisi tidak otomatis bisa menjamin kemenangan pasangan calon tertentu. Selain pilihan bebas, ada pula pengaruh kekuatan uang, hubungan keluarga dan kerabat, rekan kerja dan simpatisan.

\section{2. "Psefologi" atau "Hahonu Fatuk Fuan" (untuk) Demokrasi}

Dalam tradisi budaya Belu-Malaka, cara rakyat (renu) menentukan dan menjatuhkan pilihan politiknya dalam demokrasi terhadap seorang calon pemimpin disebut, 'hahonu fatuk fuan' atau 'hahonu batar fos'. Artinya pemilihan dan pemungutan suara dengan menggunakan sarana batu kerikil atau biji jagung. Setiap pemilih dengan bebas dapat memberikan suaranya terhadap calon pemimpin tertentu dengan cara mengambil biji jagung (batar fos) atau batu kerikil kecil (fatuk fuan) yang sudah tersedia lalu menjatuhkannya (hahonu) ke dalam satu wadah (tanasak) sebagai kotak suara. Tata cara pemilihan tradisional Belu-Malaka ini, sama dengan kebiasaan masyarakat Yunani kuno yang menggunakan batu-batu kerikil untuk menjatuhkan pilihan politiknya terhadap calon tertentu yang disebut "Psefologi" untuk demokrasi. Psefologi berasal dari akar kata psephos artinya koral atau batubatu kerilik (Aloysius Budi Purnomo, 2009).

Secara metafisik, pada masa lampau, tempat pemungutan suara dilakukan di rumah temukung (dato) atau di rumah pemali (umalulik) diawali dengan ritual adat untuk memohon restu leluhur (hamulak seti ba bei sia) dan doa kepada Wujud Tertinggi (Na'i Maromak) agar proses demokrasi berjalan lancar didasari pada prinsip rasionalitas, spiritual dan tradisi budaya yang bertanggung jawab. Di sini, istilah 'batar fos' atau 'fatuk fuan' dalam prakteknya mengandung makna pembelajaran demokrasi politik yang paling asli, jujur dan transparan (bdk. Budi Purnomo, 2009). Suatu tata cara pemilihan sungguh rasional berbasis tradisi budaya lokal, tidak sekedar eforia emosional irasional belaka, namun bernilai sakral karena keyakinan akan restu leluhur dan campur tangan Wujud Tertinggi dalam pesta 
demokrasi. Maka menjelang pesta demokrasi pilkada 9 Desember 2020, bagi para paslon bupati-waki bupati baik Kabupaten Belu dan Kabupaten Malaka, mesti memaknai masa kampanye sebagai kesempatan 'hahonu batar fos' atau 'fatuk fuan' untuk demokrasi yang benar. Artinya menjadi proses disermen demokrasi (democratic discernment) bagi para calon sendiri untuk mengkampanyekan programprogam yang sungguh-sungguh konkrit, terbukti dan menyapa kebutuhan rakyat. Sebaliknya, bagi masyarakat pemilih, masa kampanye menjadi kesempatan untuk melihat, menilai dan mengasah kecerdasan mendeteksi kecenderungan gerakan hati dan pikiran dalam mengambil keputusan menentukan pilihan politik yang tepat tanpa pengaruh dari luar.

Tujuan utama kampanye politik adalah untuk menyampaikan visi, misi dan program guna menarik simpati massa dan menggolkan sang kandidat. Aloysius Budi Purnomo dengan menyetir pemikiran Arnoldus Steinberg, dalam Political Campaign Management (1981: 261, dalam Kompas 4/6/2009) mengatakan 'psefologi demokrasi' atau dalam konteks tradisi kultural Belu-Malaka, 'fatuk fuan' demokrasi sebenarnya merupakan respons massa pemilih terhadap kampanye politik. Karena itu masa kampanye menjadi kesempatan bagi rakyat pemilih menetapkan kriteria dengan cara mencermati kualifikasi kandidat: rekam jejak kariernya, dinamika politiknya, citra pribadinya, cara kerja dan pendekatannya, penampilan lahiriahnya, cara pandangnya terhadap persoalan dan cara memberi solusi, termasuk koalisi kepartaian. Berdasarkan hasil observasi selama masa kampanye tersebut, rakyat pemilih dengan bebas memberikan dukungan politik terhadap pasangan calon tertentu ataupun menolak dengan alasan tertentu. Karena itu sebenarnya "psefologi" atau "hahonu fatuk fuan" sudah terjadi selama masa kampanye, sedangkan Hari "H-nya" pada tanggal 9 Desember 2020, rakyat pemilih Belu dan Malaka, ibarat konsumen menegaskan kepastian produk terbaiknya dari antara pasangan calon yang ada. Pada tahap ini, harapan demokrasi adalah rakyat sebagai konsumen tetap konsisten dengan sikap kritisnya. Rakyat pemilih jangan menjadi konsumen yang konsumeristik, artinya mudah terbuai dengan politik uang atau serangan fajar, terbawa oleh manuver politik yang sarat kompromi, termakan janji palsu, pragmatis, oportunistis, tebar pesona dan janji kosong.

\section{Menghembuskan Angin Tradisi Politik Metafisik Berbasis Aristokrasi}

Terkait arsitektur kekuatan "metafisika politik", sesungguhnya secara historiscultural masyarakat Belu-Malaka mengakui adanya penjelmaan kekuatan supranatural dalam diri kaum aristokrat. Raja atau ratu sebagai titisan dewa ("Maromak Oan") yang mendapat otoritas penuh untuk memerintah dan mengayomi seluruh rakyat di wilayah kekuasaannya. Salah satu strategi dinamika politik yang digunakan oleh para paslon adalah menghembuskan angin kekuasaan tradisi politik metafisik berbasis arisokrasi dalam pilkada 2020 karena pengalaman sejarah pilkada Belu pada masa lampau sudah terbukti adanya kemenangan di pihak kelompok istana.

Dengan membaca nama-nama pasangan calon dalam pilkada 2020 ini, maka saya lebih cenderung menilai ruang politik di kabupaten Belu dan kabupaten Malaka, sedang diramaikan dan didominasi oleh kekuatan 'metafisika politik' bernuansa aristokrasi-oligarki, walaupun secara sporadis diwarnai gerakan kekuatan fisik (melalui pengerahan 'mesin konkrit') dan patafisik (melalui 'citra realitas'). Artinya dalam pilkada Belu-Malaka 2020 
sebenarnya yang bertarung adalah kelompok kecil elit yang berasal dari kaum aristokrat (aristokrasi) dan kelompok oligark (oligarkhi) seraya bersinergi dengan kelompok kecil masyarakat non-bangsawan yang berpendidikan dan berpengaruh luas. Sebaliknya, kaum non istana walaupun berpendidikan tinggi dan berpengaruh dengan gelar segudang tidak begitu mudah menentukan arah politiknya tanpa bersinergi dengan kekuatan kelompok aristokrasi dan oligarkhi.

Mengapa kekuatan aristokrasi-oligarki selalu bersinergi dalam pilkada? Menurut catatan sejarah Belu, sejak kira-kira abad 4-5 atau ada yang menyebut sejak tahun 1436 orang China sudah ada di Atapupu-Belu untuk berdagang kulit sapi, kulit kerbau, hasil bumi, terutama kayu cendana dan lilin untuk kepentingan ritual keagamaan di China (Erich Breunig, 1968: 30, dalam Saku Bouk, 2012: 41,75). Ketika itu Belu masih menganut sistem aristokrasi. Raja adalah pemimpin politik dan wilayah (cujus regio) sekaligus pemimpin agama (cujus religio) dalam teritori kekuasaannya (Saku Bouk, 2012: 47). Maka untuk mendapat kesempatan berdagang di Belu, orang-orang China menggunakan dua metode pendekatan: 1)pendekatan istana (kneter ktaek umametan-ri mean) yakni orang China membangun hubungan kerjasama dagang dengan para raja di Belu. 2)pendekatan perkawinan antaretnis. Artinya dalam kerjasama dengan para raja di Belu, kelompok pedagang China memanfaatkan peluang untuk menikahi putri-putri dari kalangan istana (Saku Bouk, 2012). Dengan cara ini seorang China mendapatkan hak atas otoritas istana serentak hak dan kebebasan berdagang, sehingga ia disapa atau digelari "Na'i Baba" (Tetun) artinya 'tuan raja Belu etnis China' atau 'tuan raja Belu berdarah China'. Disebut "Na' $i$ " atau raja karena oleh perkawinan antaretnis ia sudah mendapat hak atas otoritas istana.
Disebut "Baba" karena oleh ikatan dengan istana ia mendapat kebebasan untuk berdagang. Sistem perkawinan campur antaretnis China-Belu ini melewati sejarah yang panjang sehingga berubah menjadi tradisi sampai saat ini. Hasil perkawinan campur antaretnis ini melahirkan ras campuran China-Belu yang mengokohkan ikatan kekerabatan antaretnis. Mereka memiliki status sosial ganda: 'Chinabangsawan' atau 'bangsawan-China'. China berdarah bangsawan dan bangsawan berdarah China (aristokrasi-oligarkhi atau oligarkhi-aristokrasi). Dalam bidang keagamaan kita mengenal yang mulia Mgr. Gabriel Manek, SVD: China-raja-imamuskup, berasal dari darah perkawinan Chinaputri raja di Belu (Alex Beding, 2001: 7-8). Karena itu ketika Wily Lay (China) dan dr. Agustinus Taolin (China-Raja Naitimu) tampil pada laga pilkada Belu 2020, memang tidak asing karena keduanya tentu memiliki pengetahuan dan data sejarah masa silam terkait hubungan yang tak terpisahkan antara etnis China dan keluarga bangsawan etnis Belu. Belu-Malaka adalah 'rumah sendiri' karena hubungan darah (genealogis), karena perkawinan campur etnis China-etnis Belu.

Selain kelompok pedagang China, Gereja Katolik di Belu dalam sejarah misi masa lampau, sejak misionaris Dominikan (OP) tahun 1562-1853, misionaris Serikat Yesus (SJ) dan misionaris Serikat Sabda Allah (SVD) tahun 1913, mendapatkan ruang kebebasan untuk bermisi dan membaptis banyak umat baru, justru karena adanya hubungan kerjasama yang baik antara misionaris Eropa dengan para raja di wilayah Belu. Para misionaris juga menggunakan pendekatan istana atau umametan (Saku Bouk, 2012: 46). Sebelum adanya bangunan gereja atau kapela, istana raja (umametan) menjadi 'pusat' misi, sentrum pewartaan Injil dan kegiatan liturgi. Bila seorang Liurai, Loro, Na'i, dibaptis 
menjadi Katolik, maka separuh (atau seluruh) rakyat di wilayah kekuasaannya juga memberi diri dibaptis menjadi Katolik. Jadi, sudah sejak awal, pengaruh kekuatan aristokrasi juga masuk kekuatan pergerakan misi Gereja katolik di Belu. Ketika Gereja Katolik Belu berbicara tentang otonomi wilayah misi, tentang tanah misi gereja (keuskupan, paroki, stasi, kapela), tentang pemilihan ketua dewan paroki / stasi, tentang ekonomi rakyat, tentang dinamika politik pilkada, maka Gereja tidak bisa begitu saja mengabaikan kekuatan aristokrasi yang sudah berakar di Belu. Memang, ada suara-suara yang mencoba menepis guna meredam kekuatan ini, dengan mengatakan bahwa kelompok aristokrat tidak berpengaruh lagi di Belu dan Malaka di era demokrasi ini. Tapi, de fakto kekuatan aristokrasi akan tetap tampil elok dan amat meyakinkan pada setiap pesta demokrasi di Belu dan Malaka mulai dari tingkat desa, lurah sampai kabupaten.

Kita kembali ke politik aristokrasi. Aristokrasi adalah sistem pemerintahan oleh sekelompok elit dalam masyarakat yang mempunyai status sosial, kekayaan, dan kekuasaan politik yang diwariskan turuntemurun. Jenis kekuasaan aristokrasi ini disebut pula jenis kekuasaan kaum bangsawan, kalangan istana (Tetun=umametan-ri mean). Bila ada kelas aristokrat yang dominan secara politik, maka di sana ada pula monarki (raja, ratu). Sedangkan oligarki adalah struktur kekuasaan yang didominasi oleh sekelompok orang yang memiliki kekayaan, pendidikan, keluarga, militer dan lain-lain. Dalam sistem pemerintahan kerajaan tradisonal Belu, wilayah terbesar dipimpin oleh seorang Liurai (raja tertinggi) dibantu oleh Loro (raja menengah) serta tingkat di bawah Loro adalah $\mathrm{Na} i$ (raja kecil) yang merupakan wilayah taklukan (Belanda) dalam kerjasama yang saling menyatukan dan mengokohkan satu sama lain (bdk. Beny Ulu Meak, 2014).

Tentu kita semua sepakat bahwa di kabupaten Belu dan Malaka secara de yure sistem kekuasaan aristokrasi tidak diakui karena Indonesia menganut sistem demokrasi; walaupun demikian secara de fakto, dalam kondisi riil energi kekuasaan aristokrasi-oligarki masih berpengaruh kuat mewarnai proses penentuan pemilihan calon kepala desa, lurah, pengangkatan para camat, penetapan penjabat bupati, dan paslon bupati-wakil bupati. Dalam sejarah pemerintahan daerah Belu-Malaka, kita dapat melihat deretan nama-nama yang berasal dari latar belakang keluarga istana, di antaranya : Alfons Andreas Bere Tallobupati pertama Belu berasal dari Loro Lamaknen dan $\mathrm{Na}$ 'i Kewar (A.A. Bere Talo, 1977), dr. Servas Muti Parera, Ludovikus Taolin, Herman Nai Ulu, dan deretan nama lainnya. Maka ketika kita melihat namanama paslon bupati-wakil bupati pilkada Belu-Malaka 2020, menjadi jelas bahwa pertarungan antarkandidat saat ini sebenarnya pertarungan antarinternal-istana, antar internal-Liurai, antarinternal-Loro, antarinternal-Na'i (umametan-ri mean) yang sedikit dipoles dengan kekuatan dari kelompok non bangsawan yang berpendidikan (akademisi) dan berpengaruh (birokrasi) sehingga tidak kentara. Tetapi nanti kelompok elit kecil inilah yang akan muncul ke permukaan menjadi kekuatan dominan dalam meraih kekuasaan.

Kita coba menelusuri latarbelakang setiap calon bupati-calon wakil bupati dari kedua kabupaten ini: Pertama, Kabupaten Belu. Petahana yakni Wily Lay (Malae/China - istrinya masih punya kaitan dengan Loro Fehalaran, Loro Bauho, Loro Lasiolat). Sementara penantangnya yakni dr. Agustinus Taolin (Malae/China-bernaung di bawah Loro Fehalaran-kena'i-an (kerajaan) Naitimu. Beliau sudah dinobatkan menjadi raja kerajaan (kena'i-an) Naitimu. Pada 
zaman lampau di wilayah Loro Fehalaran terdapat empat kerajaan kecil (na'i) yaitu kerajaan Lidak, Jenilu, Naitimu dan Mandeu berstatus "Oa natar hat, Oa laluan hat, Basa isin hat, Kaer kadun hat, Taka ulun hat, Sabeo hat" yang merupakan wilayah mata rantai perdagangan menuju pelabuhan Atapupu dan Batugede (Saku Bouk, 2012: 122). Kedua calon bupati ini (aristokrasioligarkhi) mengakomodir calon wakilnya dari orang-orang berpendidikan dan berpengaruh dari kalangan masyarakat biasa yang masih punya kekerabatan dengan istana. Namun yang akan tampil ke permukaan pada akhirnya adalah kelompok aristokrasi-oligarkhi. Kedua, Kabupaten Malaka. Petahana yaitu Stefanus Bria Seran (klaim diri dari Loro Hatimuk na'in) dan calon wakil bupati, Wendelinus Taolin (dari Loro Dirma-kena'i-an Rafau/Numponi dan berkaitan erat dengan kena'i-an Kusa, Sasitamean dan Babotin). Sedangkan penantang adalah Simon Nahak (anak petani tembakau berpendidikan tinggiakademisi-dosen) dan calon wakil bupati Malaka, Kim Taolin (sekeluarga-seistana dengan Wendelinus Taolin-Loro Dirmasekutu kena'i-an Kusa dan Rafau/Numponi dan berkaitan erat dengan Sasitamean dan Babotin).

Dugaan kuat bahwa politik yang didominasi oleh kekuatan 'metafisika' berbasis aristokrasi akan cenderung menggiring masyarakat pemilih BeluMalaka memilih paslon bupati dan wakil bupati yang berasal dari kalangan istana (Tetun=umametan-ri mean) karena raja dianggap sebagai titisan dewa mampu memerintah dengan penuh kewibawaan. Kalangan istana diasumsikan memiliki kekuatan supranatural. Dia memerintah atas restu leluhur, atas nama dewa dan atas perkenan Allah. Dengan membandingkan kinerja pemerintah yang sedang berkuasa saat ini, bisa dijadikan sebagai referensi untuk mengukuhkan kekuatan "metafisika politik", sekaligus cara itu dapat kembali membentuk dan menguatkan opini rakyat pemilih bahwa keputusan memilih calon kepala daerah dari kalangan istana secara genealogis terbukti memuaskan rakyat. Kekuatan "aristokrasi" yang sudah menyejarah dalam percaturan politik di Belu-Malaka selalu berupaya mengambil alih kekuatan "semiotika politik" maupun "sosiologi politik". Dengan demikian keputusan memilih tidak ditentukan oleh kekuatan pengaruh "citra realitas" dan kekuatan "demokrasi" (pemilihan dari rakyat oleh rakyat) murni $100 \%$ (bdk. Piliang, 2009), melainkan dipengaruhi pula oleh keyakinan rakyat pada kekuatan metafisika yang menjelma dalam diri paslon yang berasal dari garis keturunan Liurai, Loro, $\mathrm{Na}$ 'i. Raja digelari "Maromak Oan" artinya 'Anak Allah', titisan dewa, representasi dari yang transenden. Raja adalah simbol spiritual, lambang kehadiran yang supernatural. Raja adalah sumber kesaktian, kekuatan, kebenaran, kewibawaan dan kebijaksanaan dalam memerintah untuk menjamin keamanan wilayah dan mencapai kesejahteraan seluruh rakyatnya (Saku Bouk, 2012: 130).

Dalam pelaksanaan tugas fungsional sebagai kepala daerah, kehadirannya di antara masyarakat lebih dominan ia diterima sebagai Liurai, Loro dan $\mathrm{Na}$ 'i ketimbang sebagai Bupati-wakil bupati termasuk desa, lurah, camat dan penjabat. Demikian pula rakyat menerima seorang kepala daerah lebih sebagai raja ketimbang sebagai bupatiwakil bupati terpilih. Hal ini nampak secara simbolik dalam ungkapan-ungkapan seperti, "ama liurai....", "ama loro...", “ama na'i...", “ama na'i bupati”, “ama na'i wakil bupati", termasuk wakil rakyat, camat dan kepala desa, dalam sebutan seperti, "ama na'i DPR", ama na'i camat", ama na'i desa" atau dalam bahasa Dawan ' $R$ ' dikenal, "usi pah desa", 'usi pah camat", "usi pah DPR". Kata "na' $i$ " (Tetun) atau 
"usi", "usi pah" (Dawan R) mendahului jabatan fungsional dalam pemerintahan. Hal yang hampir sama berlaku pula dalam bidang keagamaan. Mgr. Gabriel Manek, SVD, setelah ditahbiskan menjadi imam, ketika ia datang merayakan syukur imamat di Lahurus. Orangtua, keluarga, para raja dan seluruh rakyat menerima beliau tidak hanya sebagai imam, tetapi terutama dengan penghormatn sebagai seorang raja Fialaran. Rakyat membentangkan kain dan sofren di jalan yang dilewati Pater Gabriel Manek, SVD menunggang seekor kuda pilihan mengenakan pakaian kebesaran seorang raja (Alex Beding, 2001: 29). Beliau disapa: Ama Na'i Pater Gabriel Manek, SVD atau Ama Na'i Bisbo (Uskup) Gabriel Manek, SVD. Kelompok klerus yang menjalani hidup bakti sering disapa $\mathrm{Na} i$ Pater, $\mathrm{Na} i$ Romo, $\mathrm{Na}$ ' $\mathrm{i}$ Bruder, $\mathrm{Na}$ 'i feto suster. Jabatan $n a$ ' $i$ mendahului jabatan fungsional pemerintahan, demikian pula dalam Gereja Katolik. Hal-hal ini menunjukkan adanya kekuatan budaya istana yang sangat dominan baik dalam sistem pemerintahan maupun gereja.

\section{Penutup}

Sesungguhnya ruang politik di kabupaten Belu dan kabupaten Malaka pada pilkada 2020 diramaikan oleh partai-partai koalisi untuk memenangkan pasangan calonnya, namun koalisi partai belum menjadi jaminan kemenangan, sebab secara budaya, hati masyarakat pemilih masih cenderung didominasi oleh kekuatan konsep 'metafisika politik' bernuansa aristokrasioligarki, walaupun secara sporadis diwarnai gerakan kekuatan fisik (melalui pengerahan 'mesin konkrit') dan patafisik (melalui 'citra realitas'). Itu berarti dalam pilkada BeluMalaka 2020 sebenarnya yang bertarung bukanlah partai-partai koalisi, melainkan sebaliknya, justru sekelompok kecil elit yang berasal dari kaum aristokrasi dan oligarkhi menggunakan partai-partai politik, seraya bersinergi dengan sekelompok kecil masyarakat non-bangsawan yang berpendidikan dan berpengaruh luas untuk meraih kekuasaan. Kemenangannya dalam pilkada tidak semata-mata ditentukan oleh kekuatan koalisi, melainkan juga oleh sebagian besar masyarakat pemilih yang secara budaya masih terpaut pada keyakinan akan kekuatan "politik metafisik" yang menjelma dalam diri raja sebagai pemimpim politik, titisan dewa ("Maromak Oan") yang memerintah atas restu leluhur, atas nama dewa dan perkenan Tuhan dalam memajukan wilayah dan mensejahterakan seluruh rakyat.

\section{Daftar Pustaka}

Alex beding. 2001. Mgr. Gabriel Manek, SVD-Uskup-Pendiri Tarekat Puteri Reinha Rosari. Larantuka: Trinitas Utama.

Purnomo, Aloysius Budi. 2009. [Opini] "Psefologi" (untuk) Demokrasi. Jakarta: Kompas, Kamis 4 Juni.

\section{A. A Bere Talo. 1977. Baktiku Untuk Nusa Tenggara Timur, Seri-1, Tahun 1997. Ende: Penerbit Arnoldus.}

Bouk, Hendrikus Saku. 2012. Komunikasi Misi, Societas verbi Divini TimorIndonesia 1 Maret 1913-1 Maret 2013. Kupang: Penerbit Gita Kasih.

Teni Jehanas. 2020. Berita Harian Pos Kupang, 3 September.

Piliang, Yasraf Amir. 2009. [Opini] Patafisika Politik. Jakarta: Kompas, Sabtu, 6 Juni. 


\section{Internet}

Alfons Andreas Bere Tallo (A. A. Bere Tallo), Bupati Pertama Kab. Beluhttps://www.kompasiana.com/nagi_flo res/5c93426e7a6d885c5b4916a2/alfon s-andreas-bere-tallo-a-a-bere-tallobupati-pertama-kab-belu?page $=2$ unduh 20/9/2020

Beny Ulu Meak. 2014. Menelusuri Struktur Pemerintahan Tradisional Kerajaan We Hali Di Kabupten Malaka-Timor Barathttps://oborulumeak.blogspot.com/201 4/02/menelusuri-strukturpemerintahan.html-unduh minggu 20/9/2020.

Oligarkhi-(https://ilmugeografi.com/ilmusosial/pemerintahan-oligarki-unduh, Jumat 18/9/2020). 